\title{
Analisis Konsep Forest City dalam Rencana Pembangunan Ibu Kota Negara
}

Dadang Jainal Mutaqin ${ }^{1}$, Muhajah Babny Muslim², dan Nur Hygiawati Rahayu ${ }^{3}$

${ }^{1}$ Perencana Ahli Madya di Direktorat Kehutanan dan Konservasi Sumber Daya Air, Kementerian PPN/Bappenas

${ }^{2}$ Tenaga Ahli di Direktorat Kehutanan dan Konservasi Sumber Daya Air, Kementerian PPN/Bappenas

${ }^{3}$ Direktur Kehutanan dan Konservasi Sumber Daya Air, Kementerian PPN/Bappenas

Korespondensi: dadangjm@gmail.com

Doi: doi.org/10.47266/bwp.v4i1.87| halaman: 13-29

Dikirim: 26-08-2020 | Diterima: 18-03-202 1 | Dipublikasikan: 31-03-2021

\begin{abstract}
Abstraksi
Rencana pemindahan Ibu Kota Negara (IKN) di Provinsi Kalimantan Timur memiliki tantangan besar pada aspek lingkungan terutama bagaimana memastikan pembangunan kota dapat tetap mempertahankan fungsi hutan, keanekaragaman hayati dan tidak merusak lingkungan. Konsep Forest City muncul dalam upaya mitigasi peluang kerusakan lingkungan khususnya hutan dalam perencanaan dan pembangunan IKN. Pada kajian ini diidentifikasi konsep Forest City untuk pembangunan IKN beserta prinsip, kriteria, dan indikator dengan menganalisis kondisi eksisting IKN, arah pembangunan Provinsi Kalimantan Timur dimana didalamnya terdapat calon wilayah IKN, isu dan potensi dampak lingkungan akibat pembangunan, serta dengan memperhatikan perkembangan konsep pembangunan kota di dunia (benchmarking). Berdasarkan kajian ini, konsep Forest City yang sesuai dengan kondisi calon wilayah IKN adalah kota hutan yang didominasi oleh bentang lanskap berstruktur hutan atau RTH yang memiliki fungsi jasa ekosistem seperti hutan dan dengan pendekatan lanskap yang terintegrasi untuk menciptakan kehidupan yang berdampingan dengan alam. Konsep Forest City tersebut dijabarkan menjadi enam prinsip yaitu: 1) konservasi sumber daya alam dan habitat satwa; 2) terkoneksi dengan alam; 3) pembangunan rendah karbon; 4) sumber daya air yang memadai; 5) pembangunan terkendali (Anti-Sprawl Development); 6) pelibatan masyarakat dalam mewujudkan Forest City. Setiap prinsip tersebut dijabarkan kembali berdasarkan kriteria dan indikator untuk memastikan setiap prinsip dapat terpenuhi di dalam perencanaan pembangunan IKN.
\end{abstract}

Kata kunci: Ibu Kota Negara (IKN), konsep Forest City, perencanaan kota, Kalimantan Timur. 


\title{
Analisis Konsep Forest City dalam Rencana Pembangunan Ibu Kota Negara
}

\author{
Dadang Jainal Mutaqin, Muhajah Babny Muslim, dan Nur Hygiawati Rahayu
}

\section{Pendahuluan}

Pembangunan dan perkembangan kota yang tidak terencana secara baik berpeluang memberikan dampak terhadap ekonomi, sosial dan kualitas lingkungan perkotaan terutama disebabkan oleh pertumbuhan dan migrasi penduduk. Menurut PBB (2012), lebih dari separuh penduduk dunia tinggal di kawasan perkotaan, dan trend ini akan terus berlanjut hingga tahun 2050 dimana sekitar 70 persen penduduk akan tinggal wilayah perkotaan. Pesatnya pertumbuhan penduduk di daerah perkotaan mengakibatkan meningkatnya kebutuhan lahan yang kemudian berdampak terhadap alih fungsi lahan. Alih fungsi lahan tersebut berpotensi menimbulkan degradasi lingkungan seperti banjir, penurunan muka air tanah, peningkatan suhu perkotaan dan lain sebagainya. Selain itu, urbanisasi dan pertumbuhan perkotaan yang tidak terkendali juga dapat berpengaruh terhadap perubahan iklim. Seperti yang dijelaskan IEA (2008) dengan luas hanya 2 persen dari permukaan daratan dunia, perkotaan menjadi penyumbang emisi gas rumah kaca terbesar, sekitar 70 persen emisi gas karbon dioksida $\left(\mathrm{CO}_{2}\right)$ dihasilkan dari aktivitas perkotaan, terutama sektor transportasi dan bangunan.

Keberadaan ruang terbuka hijau (RTH) dan kawasan hutan sekitar kota berkontribusi dalam mengatasi persoalan lingkungan. Fungsi RTH di kawasan perkotaan memiliki banyak manfaat seperti mengurangi panas, mencegah banjir dan penurunan muka air tanah, bahkan menyediakan ruang rekreasi dan interaksisosial. Sementara itu, hutan yang berada di sekitar kawasan perkotaan memiliki fungsi memberikan jasa ekosistem/lingkungan seperti penyedia sumber daya air, penyerap karbon, penghasil oksigen, pengatur iklim serta penyedia jasa wisata dan sumber daya ekonomi seperti kayu dan komoditas lain. Peran hutan ini cukup besar dalam mendukung keberlangsungan daerah sekitarnya atau sebagai daerah penyangga bagi daerah lain, begitu juga dengan kawasan perkotaan yang sangat bergantung pada kesehatan hutan (Seymour, 2018), baik hutan kota maupun hutan yang berada di luar kawasan perkotaan.

Hubungan antara hutan dan kota ini belum banyak disinggung dalam konsep perencanaan kota terutama untuk kota yang berada pada ekosistem sensitif seperti wilayah pesisir dataran rendah, dataran banjir, titik-titik keanekaragaman hayati dan wilayah dengan tekanan air yang tinggi. Padahal wilayah ini berpeluang tinggi terjadi degradasi lingkungan apabila tidak adanya perencanaan yang tepat, seperti halnya Wilayah Ibu Kota Baru yang direncanakan sebagai Ibu Kota Negara (IKN). IKN berada di Provinsi Kalimantan Timur yang merupakan bagian dari Pulau Kalimantan dimana pemataan ruang diarahkan untuk mewujudkan kelestarian kawasan konservasi keanekaragaman hayati dan kawasan berfungsi lindung bervegetasi hutan tropis basah paling sedikit 45 persen dari luas Pulau Kalimantan sebagai Paru-Paru Dunia. Apabila ditinjau dari kondisi saat ini, 59,50 persen luas wilayah IKN merupakan kawasan hutan yang terdiri dari kawasan hutan konservasi, kawasan hutan 
lindung dan kawasan hutan produksi. Selain memiliki kawasan hutan yang cukup luas, wilayah IKN juga termasuk ke dalam wilayah habitat satwa endemik yang dilindungi.

Perencanaan kota yang berkelanjutan sangat dibutuhkan untuk mewujudkan pelestarian alam dan lingkungan yang tetap seimbang dengan pembangunan kota, khususnya untuk perencanaan pembangunan IKN yang berada di wilayah sensitif. Konsep pengembangan kota-kota di dunia kini mulai menerapkan konsep pembangunan berkelanjutan seperti Sustainable City, Green City dan Eco city untuk mengatasi permasalahan perkotaan maupun mencegah berbagai dampak lingkungan.

Konsep perencanaan kota yang dirancang untuk mendukung pembangunan berkelanjutan sedang dikembangkan di beberapa kota di dunia, terutama kota-kota di Cina. Begitu pula di Indonesia, Pemerintah Indonesia berencana untuk membangun Ibu Kota Negara (IKN) dengan menggunakan konsep Forest City. Namun, sampai saat ini belum ada rumusan mengenai definisi maupun prinsip yang jelas dari konsep tersebut. Oleh karena itu, kajian ini akan merumuskan konsep Forest City sebagai model perencanaan kota masa depan yang lebih berkelanjutan, terutama untuk memastikan bahwa pembangunan Ibu Kota Negara memperhatikan keseimbangan antara pembangunan kota dan kelestarian alam serta lingkungan, khususnya dalam mempertahankan dan melestarikan fungsi hutan yang menjadi potensi utama di Pulau Kalimantan. Adapun tujuan dari kajian konsep Forest City dalam perencanaan IKN adalah untuk memberikan rekomendasi rencana pembangunan Ibu Kota Negara dalam upaya pelestarian hutan dan peningkatan kualitas lingkungan hidup, dengan sasaran teridentifikasinya konsep Forest City beserta prinsip, kriteria dan indikator dalam perencanaan dan pembangunan IKN.

\section{Metodologi}

Metode yang dilakukan dalam kajian adalah studi literatur untuk mengetahui kondisi terkini penerapan Forest City atau konsep pembangunan kota yang serupa dan indikatorindikator Forest City dalam aspek kebijakan, lingkungan dan prinsip ekologi. Selain itu dilakukan pengumpulan data baik primer maupun sekunder dengan beberapa metode yaitu depth interview, Focus Group Discussion, desk study, dan kunjungan lapangan.

Kerangka analisis dari kajian ini disajikan di dalam Gambar 1. Perumusan konsep Forest City akan mengacu kepada penerapan konsep perencanaan kota yang telah ada dan praktik terbaik dari penerapan konsep tersebut (benchmarking). Sedangkan, prinsip, kriteria dan indikator Forest City di IKN akan dirumuskan berdasarkan isu kehutanan dan lingkungan hidup di IKN, isu pembangunan kota secara umum, pedoman pembangunan berkelanjutan, arahan pembangunan Pulau Kalimantan dan Provinsi Kalimantan Timur, juga dirumuskan berdasarkan konsep yang menjadi bagian dari proses benchmarking yang disesuaikan dengan kebutuhan pembangunan Forest City di Indonesia khususnya IKN. 


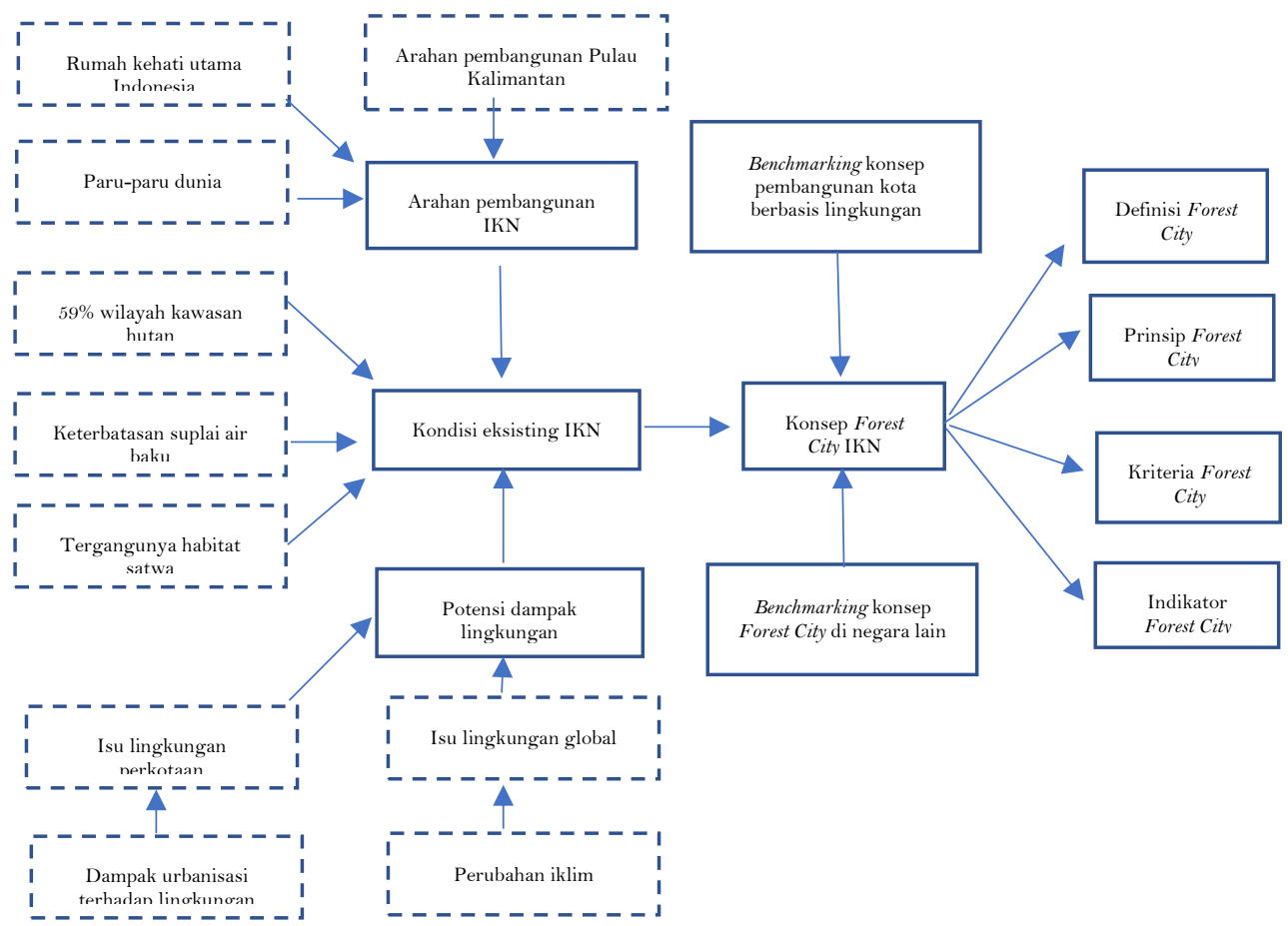

Gambar 1. Kerangka Analisis

\section{Analisis}

\subsection{Kondisi Eksisting Wilayah IKN dan Arahan Pembangunan}

Calon wilayah IKN terletak di Provinsi Kalimantan Timur, tepatnya di Kabupaten Penajam Paser Utara dan Kabupaten Kutai Kartanegara. Posisi IKN ini berada pada wilayah strategis perlindungan keanekaragaman hayati (kehati) yang terletak di Provinsi Kalimantan Timur, yang merupakan bagian dari pulau Kalimantan. Pulau ini juga disebut sebagai Borneo dan ditetapkan sebagai "Paru-Paru Dunia" karena memiliki hutan dengan kekayaan keanekaragaman hayati yang cukup banyak dan berperan penting dalam penyerapan karbon dan penyedia oksigen. Arahan penataan ruang pulau Kalimantan adalah untuk mewujudkan kelestarian kawasan konservasi keanekaragaman hayati dan kawasan berfungsi lindung bervegetasi hutan tropis basah paling sedikit 45 persen dari luas pulau Kalimantan sebagai "Paru-Paru Dunia", sesuai dengan Peraturan Presiden No. 3 Tahun 2012 tentang Tata Ruang Pulau Kalimantan. Menurut Peraturan tersebut, Paru-Paru Dunia adalah kawasan bervegetasi hutan tropis basah dalam satu hamparan luas yang memiliki fungsi sebagai penyerap karbondioksida, penghasil oksigen, dan penyeimbang iklim global. Kebijakan pulau Kalimantan sebagai Paru-Paru Dunia meliputi pelestarian kawasan yang memiliki keanekaragaman hayati tumbuhan dan satwa endemik, pengembangan koridor ekosistem antarkawasan konservasi, pemantapan dan rehabilitasi kawasan berfungsi lindung dan pengendalian kegiatan budi daya yang berpotensi mengganggu kawasan berfungsi lindung. 
Wilayah IKN memiliki Kawasan Hutan seluas 108.364,48 ha dengan tipe ekosistem yang beragam seperti ekosistem padang lamun, mangrove, rawa, hutan pantai, kerangas, dan hutan tropis dataran rendah. Berdasarkan status lahannya, kawasan Hutan di IKN terdiri dari kawasan Hutan Konservasi pada Tahura Bukit Soeharto, kawasan Hutan Produksi dan kawasan Hutan Lindung. Selain itu, di IKN juga terdapat kawasan yang diidentifkasi sebagai daerah bernilai konservasi tinggi yang merupakan kawasan dengan ekosistem langka sebagai habitat satwa dan perlindungan sempadan sungai, yang disebut juga dengan Daerah NKT1 dan NKT3.
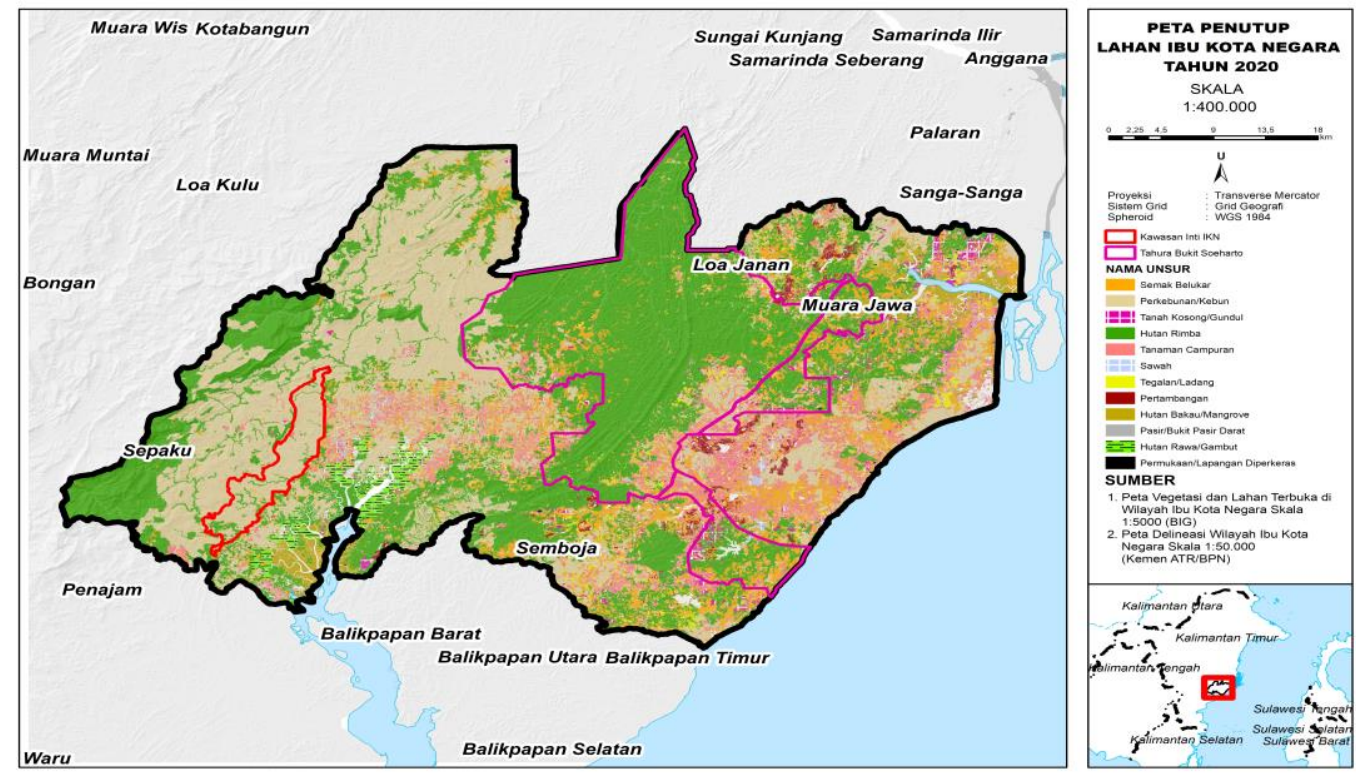

Gambar 2. Peta Penutupan Lahan Wilayah IKN

Sumber: Diolah dari peta penutupan Lahan BIG

Wilayah IKN memiliki Kawasan Hutan Produksi seluas 63.434 ha dari luas IKN sebesar 256.654 ha. Di dalam Kawasan Hutan Produksi ini terdapat 2 konsesi, yang dimiliki oleh PT. ITCI Hutani Manunggal (PT IHM) seluas 37.314 ha dan PT Inhutani I Batu Ampar seluas 16.058 ha. Areal konsesi PT IHM termasuk ke dalam wilayah IKN yang terletak di Kecamatan Loakulu Kabupaten Kutai Kartanegara dan Kecamatan Sepaku dan Kecamatan Penajam di Kabupaten Penajam Paser Utara di Provinsi Kalimantan Timur. Luas Konsesi PT IHM mencapai 63.434 ha dari seluruh luas lahan yang ada di Provinsi Kalimantan Timur dengan masa konsesi akan berakhir hingga 2042. Sebagian luas konsesi IHM ini ternyata juga berada pada Tahura Bukit Soeharto dengan luas 292 ha.

Selain kawasan hutan produksi, Wilayah IKN juga memiliki kawasan Hutan Konservasi yaitu Tahura Bukit Soeharto seluas 64.814 ha dari luas IKN sebesar 256.654 ha. Tahura Bukit Soeharto memiliki tipe ekosistem hutan campuran Dipterocarpaceae dataran rendah, hutan kerangas, hutan pantai, semak belukar, dan alang-alang (UPTD Tahura Bukit Soeharto, 2019). Kawasan Tahura Bukit Soeharto pada saat ini telah berubah sebagai ekosistem hutan tanaman yang merupakan upaya rehabilitasi dengan berbagai jenis tanaman seperti Acasia (Acasia mangium), Sengon (Albizia paraserianthes), dan Mahoni (Swietenia 
mahagoni). Flora asli didominasi jenis Meranti (Shorea spp.), dan sebagian merupakan hutan penelitian berupa persemaian berbagai jenis tumbuhan seperti Mahang (Macaranga hypoleuca), Ulin (Eusideroxylon zwageri), Kayu arang (Diospyros borneensis), Kempas (Koompassia malaccensis), Palaman (Iristania spp.), Resak (Vatica spp.), Bayur (Pterospermum spp.), Gmelina (Gmelina arborea), Karet (Hevea brasiliensis), Rotan (Calamus spp.), Aren (Arenga pinnata), dan Ketapang (Terminalia catappa). Di kawasan Tahura Bukit Soeharto juga terdapat 46 Jenis Mamalia dan hewan lainnya yang sebagian besar merupakan species yang dilindungi.

Wilayah IKN memiliki keanekakaragaman hayati (kehati) yang sangat beragam. Sebaran kehati di wilayah IKN ditandai dengan jumlah tumbuhan di Kalimantan Timur sekitar 527 jenis tumbuhan, 180 jenis burung, lebih dari 100 mamalia, 25 jenis herpetofauna dan terdapat spesies dengan status konservasi tinggi, dilindungi, endemik, dan spesies penting. Menurut Hasil KLHS Masterplan IKN (KLHK, 2020), terdapat spesies dengan status konservasi tinggi, dilindungi, endemik dan spesies penting. Sebaran spesies penting ini dapat dijumpai di Kawasan Hutan Produksi, Kawasan Hutan Lindung yang berada di sekitar wilayah IKN dan Kawasan Pelestarian Alam berupa burung endemik, Orangutan, Beruang Madu, Lutung Merah, Owa Kelawat, Macan Dahan, Kucing Hutan, Rusa Sambar dan lainnya. Selain itu, juga telah teridentifikasi 33 jenis dipterokarpa yang berada di KHDTK Samboja, 35 jenis yang berada di konsesi ITCIKU, dan 25 jenis berada di Hutan Lindung Sungai Wain. Tabel 1 memperlihatkan daftar status species di wilayah IKN.

Tabel 1. Daftar Status Spesies di Wilayah IKN

\begin{tabular}{|c|c|c|c|c|}
\hline Nama latin & Nama Lokal & $\begin{array}{c}\text { Ordo/famil } \\
\text { i }\end{array}$ & $\begin{array}{c}\text { Permen LHK } \\
\text { P.106/2018 }\end{array}$ & IUCN Redlist \\
\hline Pongo pymeus morio & orangutan kalimantan & Primata & Dilindungi & $\begin{array}{l}\text { Critical } \\
\text { Endangered }\end{array}$ \\
\hline Nasalis larvatus & bekantan & Primata & Dilindungi & $\begin{array}{l}\text { Critical } \\
\text { Endangered }\end{array}$ \\
\hline Presbytis rubicunda & Lutung Merah & Primata & Dilindungi & Vulnerable \\
\hline $\begin{array}{l}\text { Trachypithecus } \\
\text { cristatus }\end{array}$ & Lutung Kelabu & Primata & Dilindungi & $\begin{array}{l}\text { Near } \\
\text { Treathened }\end{array}$ \\
\hline Hylobates muelleri & Owa Kelawat & Primata & Dilindungi & Endangered \\
\hline Tarsius bancanus & Krabuku Ingkat & Primata & Dilindungi & Endangered \\
\hline Nycticebus sp. & Kukang & Primata & Dilindungi & Endangered \\
\hline Macaca nemestrina & Beruk & Primata & $\begin{array}{c}\text { Tidak } \\
\text { Dilindungi } \\
\end{array}$ & Endangered \\
\hline Macaca fascicularis & Monyet Ekor panjang & Primata & $\begin{array}{c}\text { Tidak } \\
\text { Dilindungi } \\
\end{array}$ & Least Concern \\
\hline Helarctos malayanus & Beruang Madu & Karnivora & Dilindungi & Vulnerable \\
\hline Neofelis diardi & Macan Dahan & Karnivora & Dilindungi & Endangered \\
\hline $\begin{array}{l}\text { Prionailurus } \\
\text { bengalensis }\end{array}$ & Kucing hutan & Karnivora & Dilindungi & Least Concern \\
\hline Pardofelis marmorata & kucing batu & Karnivora & Dilindungi & $\begin{array}{l}\text { Near } \\
\text { Treathened }\end{array}$ \\
\hline Catopuma badia & Kucing emas & Karnivora & Dilindungi & Endangered \\
\hline Arctictis binturong & Binturong & Karnivora & Dilindungi & Vulnerable \\
\hline Iomys horsfieldi & Tupai terbang & Rodentia & Dilindungi & Least Concern \\
\hline
\end{tabular}




\begin{tabular}{|c|c|c|c|c|}
\hline Nama latin & Nama Lokal & $\begin{array}{c}\text { Ordo/famil } \\
\text { i }\end{array}$ & $\begin{array}{c}\text { Permen LHK } \\
\text { P.106/2018 }\end{array}$ & IUCN Redlist \\
\hline Cynogale bennettii & Musang Air & Karnivora & Dilindungi & Endangered \\
\hline Rusa unicolor & Rusa Sambar & $\begin{array}{l}\text { Cetartiodact } \\
\text { yla }\end{array}$ & Dilindungi & Vulnerable \\
\hline Muntiacus atherodes & Kijang Kuning & $\begin{array}{l}\text { Cetartiodact } \\
\text { yla }\end{array}$ & Dilindungi & Least Concern \\
\hline Muntiacus muntjak & Kijang muncak & $\begin{array}{l}\text { Cetartiodact } \\
\text { yla }\end{array}$ & Dilindungi & Least Concern \\
\hline Rhinoplax vigil & Rangkong Gading & $\begin{array}{l}\text { Bucerotifor } \\
\text { mes }\end{array}$ & Dilindungi & $\begin{array}{l}\text { Critical } \\
\text { Endangered }\end{array}$ \\
\hline Rhyticeros undulatus & Julang Emas & $\begin{array}{l}\text { Bucerotifor } \\
\text { mes }\end{array}$ & Dilindungi & Vulnerable \\
\hline Buceros rhinoceros & Julang Cula & $\begin{array}{l}\text { Bucerotifor } \\
\text { mes }\end{array}$ & Dilindungi & Vulnerable \\
\hline $\begin{array}{l}\text { Anthracoceros } \\
\text { malayanus }\end{array}$ & Kangkareng hitam & $\begin{array}{l}\text { Bucerotifor } \\
\text { mes }\end{array}$ & Dilindungi & Vulnerable \\
\hline $\begin{array}{l}\text { Rhabdotorrhinus } \\
\text { corrugatus }\end{array}$ & Julang Jambul hitam & $\begin{array}{l}\text { Bucerotifor } \\
\text { mes }\end{array}$ & Dilindungi & Endangered \\
\hline $\begin{array}{l}\text { Anthracoceros } \\
\text { albirostris }\end{array}$ & Kangkareng Perut Putih & $\begin{array}{l}\text { Bucerotifor } \\
\text { mes }\end{array}$ & Dilindungi & Endangered \\
\hline Manis javanica & Trenggiling & Manidae & Dilindungi & $\begin{array}{l}\text { Critical } \\
\text { Endangered }\end{array}$ \\
\hline Tragulus javanicus & Peladuk Kancil & Tragulidae & Dilindungi & Data Deficient \\
\hline Gracula religiosa & Beo/Tiong Emas & Sturnidae & Dilindungi & Least Concern \\
\hline Lophura bulweri & Serindit/sempidan Kalimantan & Phasianidae & Dilindungi & Vulnerable \\
\hline Haliastur indus & Elang Bondol & $\begin{array}{l}\text { Accipitrifor } \\
\text { mes }\end{array}$ & Dilindungi & Least Concern \\
\hline Crocodylus porosus & Buaya muara & $\begin{array}{l}\text { Crocodylida } \\
\mathrm{e}\end{array}$ & Dilindungi & Least Concern \\
\hline Dugong dugon & Dugong & Dugongidae & Dilindungi & Vulnerable \\
\hline Orcaella brevirostris & Pesut Mahakam & Delphinidae & Dilindungi & Vulnerable \\
\hline Chelonia mydas & Penyu Hijau & Cheloniidae & Dilindungi & Endangered \\
\hline $\begin{array}{l}\text { Neophocaena } \\
\text { phocaenoides }\end{array}$ & Lumba-lumba hitam tak bersirip & Phocoenidae & Dilindungi & Vulnerable \\
\hline Tursiops aduncus & $\begin{array}{l}\text { Lumba-lumba Hidung Botol } \\
\text { Indo-pasifik }\end{array}$ & Delphinidae & Dilindungi & $\begin{array}{l}\text { Near } \\
\text { Treathened }\end{array}$ \\
\hline
\end{tabular}

Sumber: Inventarisasi Data KLHS Masterplan IKN (2020).

\subsection{Potensi Dampak Lingkungan}

Terdapat beberapa potensi dampak lingkungan pembangunan IKN. Adapun potensi dampak lingkungan tersebut yang perlu dipertimbangkan dalam perumusan konsep Forest City untuk rencana pembangunan IKN adalah sebagai berikut:

\section{a. Degradasi hutan di wilayah IKN}

Wilayah IKN memiliki tantangan pembangunan pada sektor kehutanan yang cukup signifikan terutama degradasi hutan. Degradasi hutan ditunjukkan oleh menurunnya tutupan hutan, yang salah satunya disebabkan oleh adanya pemanfaatan lahan di dalam kawasan hutan untuk kegiatan nonkehutanan seperti pertambangan, permukiman dan bahkan perkebunan (tumpang tindih perizinan konsesi Hutan Produksi di Tahura Bukit Soeharto). Padahal Wilayah IKN termasuk bagian dari Pulau Kalimantan yang arahan penataan ruangnya untuk mewujudkan kelestarian kawasan konservasi keanekaragaman 
hayati dan kawasan berfungsi lindung bervegetasi hutan tropis basah paling sedikit 45 persen dari luas Pulau Kalimantan sebagai Paru-Paru Dunia. Oleh karena itu, Konsep Forest City dalam rencana pembangunan IKN harus memperhatikan dan melestarikan hutan serta kawasan lindung lainnya untuk melindungi keanekargaman hayati dan memaksimalkan penyerapan karbon serta mendukung pembangunan kota berkelanjutan.

\section{b. Ancaman terhadap habitat satwa}

Wilayah IKN dan sekitarnya termasuk bagian dari Pulau Kalimantan yang merupakan salah satu rumah kehati utama di Indonesia, yang ditandai dengan beragamnya jenis satwa dan tumbuhan, termasuk beberapa spesies yang dikategorikan dilindungi atau penting. Keberlangsungan satwa dan tumbuhan ini mulai terancam akibat adanya potensi degradasi habitat satwa. Selain itu terdapat juga beberapa kasus konflik satwa dengan manusia seperti yang teridentifikasi di daerah Teluk Balikpapan (buaya, pesut dan bekantan).

\section{c. Potensi emisi karbon dari pembukaan lahan berhutan}

Pembangunan IKN membutuhkan lahan baru terutama dalam pembangunan kota. Hal ini juga dapat berpeluang menciptakan konversi lahan dari kawasan hutan. Total emisi akibat pembangunan IKN di lahan seluas 56.000 ha diperkirakan mencapai 2,4 juta ton $\mathrm{CO}_{2}$ Equivalen yang bersumber dari hutan sekunder 29 ribu ton $\mathrm{CO}_{2}$ Equivalen dan hutan tanaman 154 ribu ton $\mathrm{CO}_{2}$ Equivalen (Sulistioadi et al., 2004).

\section{d. Keterbatasan supply air baku}

Berdasarkan analisis kondisi saat ini dari KLHS Masterplan IKN, daya dukung air di wilayah IKN (256.000 ha) sudah terlampaui namun akses penduduk untuk mendapatkan air bersih masih rendah, begitu juga dengan kawasan IKN (56.000 ha). Ketersediaan air di kawasan IKN termasuk rendah karena kawasan ini merupakan daerah non-CAT (Cekungan Air Tanah). Daerah non-CAT memiliki kemampuan resapan air yang rendah sehingga tidak bisa mengandalkan air tanah (ground water).

\section{e. Potensi banjir}

Kawasan IKN memiliki potensi bencana banjir karena ada daerah yang masuk ke dalam kawasan rawan bencana banjir seperti di Kecamatan Sepaku, Samboja, dan Muara Jawa dan terutama di sekitar daerah aliran sungai.

\subsection{Perkembangan Konsep Forest City}

Terminologi Forest City cukup jarang ditemukan di berbagai penelitian ilmiah sehingga banyak yang berpikir bahwa Forest City sama dengan urban forest. Urban forest mulai dikenal ketika penelitian terkait urban forestry pertama kali digagas di Amerika Serikat pada tahun 1960-an sebagai pendekatan integratif dalam perencanaan dan pengelolaan sumber daya pohon perkotaan (Bentsen et al., 2020). Sejak itu, hutan memainkan peran yang cukup penting dalam pemeliharaan dan peningkatan ekologi lingkungan perkotaan. Beberapa jurnal menyebutkan bahwa, Forest City merupakan sebuah gagasan dalam perencanaan kota yang memiliki karakteristik adanya dominasi vegetasi atau penghijauan di perkotaan yang dapat juga berupa vertical forest (Guan et al., 2018).

Istilah Forest City mulai dikenal dalam perencanaan dan pembangunan kota sejak abad ke-18 di Ohio, Cleaveland yang mendapatkan julukan Forest City karena memiliki kepadatan 
pohon yang tinggi. Istilah ini juga sempat diklaim oleh London, Canada yang menyebutkan kotanya sebagai The Forest City karena membangun permukiman di tengah hutan. Kemudian di Abad ke-20 istilah ini mulai digunakan, terutama di beberapa kota yang dirancang oleh Arsitektur Stefano Boeri dan konsep perencanaan kota di Cina. Konsep Forest City ini juga banyak diadopsi dari berbagai konsep pembangunan kota yang pernah ada seperti sustainable city, eco city, green city dan smart city. Oleh karena itu, dapat juga dikatakan bahwa konsep ini merupakan pengembangan dari berbagai konsep perencanaan kota tersebut yang sangat memperhatikan keberlanjutan kota.

Forest City diterjemahkan oleh Stefano Boeri sebagai vertical forest sehingga Forest City dapat juga dikatakan sebagai kota dengan jumlah bangunan yang ditutupi oleh pohon dan tumbuhan. Pohon tersebut berperan sebagai penyaring udara raksasa dan pengendali polusi yang dengan metode vertical foresting diharapkan dapat mengembalikan ruang secara alami sebagai upaya perlindungan bumi. Vegetasi di perkotaan dipercaya dapat menurunkan suhu udara, menciptakan penghalang kebisingan dan meningkatkan keanekaragaman hayati dengan menyediakan habitat bagi burung, serangga, dan hewan kecil lainnya.

Pada beberapa contoh rencana pembangunan kota, konsep ini didefinisikan sebagai suatu upaya untuk menghutankan kembali kota-kota akibat dari dampak pembangunan terutama pencemaran dan kerusakan lingkungan. Konsep Forest City ini cukup masif berkembang di Cina, yang merupakan bentuk perbaikan kualitas lingkungan perkotaan khususnya persoalan polusi udara terutama pada kota-kota besar di Cina yang memiliki industri yang didominasi oleh industri berat. Cina juga merupakan salah satu negara yang memiliki pertumbuhan urbanisasi tercepat di dunia dengan jumlah penduduk perkotaan sebesar 800 juta penduduk dan diprediksi pada tahun 2030 mencapai 1 Milyar penduduk (CDIC, 2018). Lebih dari 200 kota di 18 provinsi sudah terlibat dalam rencana pembangunan Forest City sejak 2004 lalu. Sebanyak 138 kota telah berstatus Forest City dengan rata-rata peningkatan kawasan hutannya mencapai 13.333 ha selama lima tahun terakhir.

Konsep Forest City di Cina sangat berkaitan erat dengan hutan kota buatan serta bangunan hijau yang merupakan komponen utama dari pembangunan ekologi perkotaan sehingga Cina dijuluki sebagai "World's largest man-made forest" namun sebagai suatu negara Cina memiliki kekurangan akan hutan dan vegetasinya terutama di kota-kota besarnya. Hutan disini juga dapat disebut sebagai “animated urban infrastructure” yang memiliki fungsi untuk restorasi ekosistem perkotaan (Roy et al., 2012). Beberapa penelitian menunjukkan bahwa sistem hutan di perkotaan dapat mengatur dan memblokir $\mathrm{PM}_{2.5}$, sulfur dioksida, dan nitrogen oksida, yang dengan ini dapat mengurangi pembentukan kabut asap, seperti yang berkembang di Cina. Tujuan utama Konsep Forest City di Cina adalah untuk mengatasi persoalan polusi udara terutama pada kota-kota besar di Cina yang memiliki industri yang didominasi oleh industri berat. Konsep ini dinilai dapat menjawab berbagai permasalahan khususnya dengan fungsi ekologi dari Forest City yakni menyediakan cara baru untuk mitigasi dan menangani masalah polusi dalam konteks regional hingga dapat menciptakan lingkungan perkotaan yang layak huni, seperti yang dijelaskan Shao \& Xie (2019) bahwa Forest City adalah cara efektif untuk mengurangi pemanasan lingkungan atmosfer dan mengatasi emisi gas rumah kaca. Xu et al (2020) juga menjelaskan bahwa fungsi jasa ekologi dari Forest Cities dapat mengurangi polusi yang disebabkan oleh pertumbuhan industrialisasi dan urbanisasi yang cepat sampai batas tertentu, seperti memperbaiki iklim mikro perkotaan, 
mencegah erosi tanah, mengurangi angin, pasir dan efek urban heat island. Hal ini juga dibuktikan dari hasil penelitian Xu et al. (2020) yang menunjukkan bahwa pembangunan Forest City berdampak terhadap kualitas udara di aglomerasi perkotaan Beijing-TianjinHebei yakni dengan mengurangi konsentrasi $\mathrm{PM}_{2.5}$. Berikut definisi Forest City dari berbagai terminologi yang digunakan pada beberapa penelitian terkait (Tabel 2), penggunaan terminologi Forest City pada kota-kota di dunia, dan perumusan konsep pada FGD Konsep Forest City yang telah dilakukan dalam kajian ini.

Tabel 2. Definisi Forest City dari Berbagai Sumber

\begin{tabular}{|c|c|c|}
\hline No & Sumber & Definisi/makna \\
\hline \multicolumn{3}{|c|}{ Jurnal Ilmiah } \\
\hline 1 & $\begin{array}{l}\text { Guan, dkk } \\
(2018)\end{array}$ & $\begin{array}{l}\text { "As the other new urban form, the Forest City increases the number of plants, } \\
\text { especially trees, and greatly increase the rate of greening". } \\
\text { "The planning of this program, based on the "vertical forest". }\end{array}$ \\
\hline 2 & $\mathrm{Xu}, \mathrm{dkk}(2020)$ & $\begin{array}{l}\text { Forest City is a typical urban complex ecosystem that is dominated by forest vegetation } \\
\text { which enables the forest to be used in multi-functions and multi-effectiveness. }\end{array}$ \\
\hline \multicolumn{3}{|c|}{ Penggunaan Terminologi Forest City pada Kota - Kota di Dunia } \\
\hline 1 & $\begin{array}{l}\text { City in the } \\
\text { Forest Atlanta }\end{array}$ & $\begin{array}{l}\text { Julukan terhadap Kota Atlanta karena memiliki tutupan pohon yang hampir } \\
\text { setengah dari luas wilayah kota ( } 48 \% \text { dari luas Kota Atlanta). }\end{array}$ \\
\hline 2 & $\begin{array}{l}\text { The Forest City } \\
\text { London }\end{array}$ & $\begin{array}{l}\text { Julukan terhadap Kota London, Canada yang wilayah perkotaan berasal dari } \\
\text { kawasan hutan atau memiliki vegetasi hutan yang cukup besar. The Forest City } \\
\text { didefinisikan juga sebagai urban forest yang mengacu pada semua pohon yang ada di } \\
\text { kota terlepas dari jenis penggunaan lahan maupun kepemilikannya. }\end{array}$ \\
\hline 3 & $\begin{array}{l}\text { Smart Forest } \\
\text { City Cancun }\end{array}$ & Konsep pengembangan kota berdasarkan inovasi teknologi dan kualitas lingkungan \\
\hline 4 & $\begin{array}{l}\text { Liuzhou Forest } \\
\text { City }\end{array}$ & $\begin{array}{l}\text { Pembangunan kota untuk mengendalikan polusi udara dan permasalahan } \\
\text { lingkungan lainnya }\end{array}$ \\
\hline 5 & $\begin{array}{l}\text { Forest City } \\
\text { Shijiazhuang }\end{array}$ & $\begin{array}{l}\text { Model kota dengan pertumbuhan berkelanjutan yang merupakan prototype kota yang } \\
\text { tersusun oleh vertical forest; sebuah ekosistem perkotaan; instrumen untuk mencegah } \\
\text { urban sprawl; kota berkelanjutan dengan konsumsi energi rendah; penyerap } \mathrm{CO}_{2} \text { dan } \\
\text { polusi perkotaan; pengganda keanekaragaman hayati; landmark kota; elemen dasar } \\
\text { dari model baru urbanisasi di Cina. }\end{array}$ \\
\hline \multicolumn{3}{|c|}{ Focus Group Discussion Konsep Forest City } \\
\hline 1 & Konsep 1 & $\begin{array}{l}\text { Konstruksi hutan atau membangun kembali hutan di perkotaan untuk memperbaiki } \\
\text { lingkungan dan ekosistem di kota serta terciptanya keseimbangan hidup yang } \\
\text { berdampingan antara manusia dengan spesies lain. }\end{array}$ \\
\hline 2 & Konsep 2 & $\begin{array}{l}\text { Kota hutan yang bentang lanskapnya didominasi oleh bentang lanskap berstruktur } \\
\text { hutan atau RTH yang memiliki fungsi jasa ekosistem seperti hutan dan dengan } \\
\text { pendekatan lanskap yang terintegrasi untuk menciptakan kehidupan yang } \\
\text { berdampingan dengan alam. }\end{array}$ \\
\hline
\end{tabular}

Sumber: Guan et al. (2018); Xu et al., (2020); Atlanta Magazine (2015); Architetti (2020); B.A. Blackwell and Associates Ltd (2014).

Dari berbagai definisi Forest City pada tabel di atas, dapat disimpulkan bahwa Forest City identik dengan

- julukan untuk kota yang dibangun dari kawasan hutan;

- kota dengan dominasi vegetasi hutan atau memiliki tutupan pohon yang luas; 
- urban forest;

- konsep menghutankan kembali atau konstruksi hutan untuk memperbaiki ekosistem kota dan menciptakan keseimbangan hidup yang berdampingan antara manusia dan spesies lain;

- kota rimba yang bentang lanskapnya berstruktur seperti hutan atau memiliki fungsi jasa ekosistem seperti hutan.

- tersedianya vertical forest, RTH termasuk hutan kota, dan tutupan area hijau di perkotaan yang luas.

\subsection{Konsep Forest City Dalam Rencana Pembangunan IKN}

Pendefinisian Forest City untuk pembangunan IKN akan berbeda dengan konsep Forest City yang selama ini sudah berkembang di beberapa negara pada contoh sebelumnya. Hal ini karena lokasi IKN yang berada di dalam dan sekitar kawasan hutan dan memiliki keanekaragaman hayati tinggi sehingga dalam perencanaan dan pembangunannya perlu difokuskan pada upaya untuk mempertahankan dan merestorasi hutan. Penerapan konsep Forest City di IKN tidak seperti contoh penerapan konsep tersebut di kota lain yang menghutankan kembali kotanya yang telah terbangun dengan penyediaan RTH. Namun, pendefinisian ini tetap merujuk pada beberapa hal atau ciri yang telah dikembangkan seperti dominasi vegetasi hutan, dan tutupan pohon yang luas karena masih relevan dengan kondisi dan kebutuhan pembangunan IKN. Oleh karena itu, definisi Forest City yang lebih sesuai untuk rencana pembangunan kota baru di Wilayah IKN adalah sebagai berikut:

"Kota hutan yang didominasi oleh bentang lanskap berstruktur hutan atau RTH yang memiliki fungsi jasa ekosistem seperti hutan dan dengan pendekatan lanskap yang terintegrasi untuk menciptakan kehidupan yang berdampingan dengan alam”.

Di dalam konsep pembangunannya, Forest City akan dirancang sesuai kondisi alam untuk menciptakan kehidupan yang berdampingan dengan alam, dengan tujuan mendukung pembangunan berkelanjutan khususnya memaksimalkan penyerapan karbon dan konservasi keanekaragaman hayati, serta pengelolaan lingkungan untuk meningkatkan kualitas lingkungan hidup.

Konsep Forest City secara lebih jelasnya dapat dilihat berdasarkan Prinsip, Kriteria dan Indikator. Prinsip Forest City adalah asas atau pokok dasar yang menjadi acuan dalam Konsep Forest City yang mengacu kepada pembangunan kota yang dapat mempertahankan fungsi ekologis hutan dan tujuan pembangunan dalam konsep Forest City lainnya seperti penyerapan karbon, konservasi keanekaragaman hayati, dan pengelolaan lingkungan untuk meningkatkan kualitas lingkungan hidup. Prinsip ini merupakan payung perumusan Kriteria dan Indikator. Kriteria adalah ukuran yang menjadi dasar penilaian atau penetapan sesuatu yang dapat juga dikatakan sebagai standar untuk mencapai kondisi ideal atau standar untuk mengetahui/menilai apakah kemajuan yang dicapai dapat memenuhi Prinsip. Sedangkan indikator merupakan komponen atau variabel yang mencerminkan atau mengindikasikan situasi atau kondisi yang diperlukan oleh kriteria.

Kementerian Lingkungan Hidup dan Kehutanan (KLHK) pada tahun 2019 telah merumuskan beberapa prinsip Forest City untuk perencanaan Calon Ibu Kota Negara sebagai rekomendasi dari hasil KLHS Rapid Assessment yang meliputi 
1) Berbasis pengelolaan DAS;

2) Memiliki jaringan ruang hijau yang terstruktur;

3) Memanfaatkan sekitar 50 persen wilayah untuk dikembangkan;

4) Konsumsi air harus sangat efisien;

5) Beban pemenuhan konsumsi penduduk rendah;

6) Memiliki kualitas udara yang baik dan suhu udara rata-rata sejuk;

7) Memiliki kualitas air permukaan yang baik;

8) Melindungi habitat satwa;

9) Memiliki kualitas tutupan lahan yang baik dan terevitalisasinya lansekap "Hutan Hujan Tropis”.

Prinsip Forest City yang telah disusun oleh KLHK tersebut dapat menjadi pedoman dalam perencanaan dan pembangunan Wilayah IKN secara keseluruhan, seluas 256.000 ha. Namun, untuk menerapkan prinsip tersebut dalam pembangunan kota perlu disesuaikan kembali agar penerapannya tepat pada konteks kota maupun perkotaan dan dapat menjadi contoh untuk penerapan Konsep Forest City di kota lain. Selain itu, prinsip Forest City harus mengacu kepada visi pembangunan IKN menjadi kota paling berkelanjutan di dunia, serta benchmarking dari beberapa kota yang menerapkan Forest City. Beberapa prinsip Forest City untuk Kawasan IKN seluas 56.000 Ha yaitu sebagai berikut:

\section{Prinsip 1. Konservasi sumber daya alam dan habitat satwa}

Pembangunan kota hendaknya meminimalkan kerusakan ekosistem alami yang ada atau justru dapat mempertahankan ekosistem alami tersebut (termasuk habitat alami bagi satwa maupun tumbuhan) dan menjamin keberlanjutan hutan dengan melindungi maupun merestorasi kembali ekosistem hutan untuk perbaikan kualitas lingkungan. Dengan kondisi IKN sebagai fokus dalam kajian ini yang mayoritas lahannya merupakan kawasan hutan, perlu menciptakan kota yang dibangun di dalam hutan dengan tingkat kepadatan yang menengah untuk memastikan ketersediaan pertumbuhan biomassanya tetap menjadi canopy. Hal ini juga untuk menjamin bahwa IKN tetap dapat mendukung peran Kalimantan sebagai Paru-Paru Dunia.

\section{Prinsip 2. Terkoneksi dengan alam}

Pada dasarnya prinsip ini berupaya untuk menciptakan pembangunan kota yang dapat mengakomodasi interaksi manusia dengan alam atau terkoneksi dengan alam (connected with nature) dan hutan di dalam dan sekitar kota. Prinsip ini dapat diterapkan dengan penyediaan RTH pada kawasan perkotaan, termasuk koridor hijau. Connected with nature juga dapat diwujudkan dengan dominasi lansekap berupa vegetasi hijau antara bangunan, yaitu zona hijau untuk rekreasi dan kehidupan yang saling terintegrasi.

\section{Prinsip 3. Pembangunan rendah karbon}

Prinsip ini untuk mendukung kebijakan nasional mengenai penurunan emisi gas rumah kaca dan memaksimalkan peran pohon maupun hutan dalam penyerapan karbon serta untuk memperbaiki kualitas udara yang juga harus didukung dari penggunaan energi baru dan terbarukan.

\section{Prinsip 4. Pembangunan sumber daya air yang memadai}


Prinsip pembangunan sumber daya air yang memadai menitikberatkan pada pengelolaan sumber daya air yang berkelanjutan untuk menjamin ketersediaan dan kualitas sumber daya air di Kawasan IKN yang memiliki kondisi ketersediaan air rendah. Penyediaan sumber daya air dapat dilakukan dengan menyediakan penampungan air hujan (seperti pembangunan waduk, embung dan tampungan air lainnya) maupun penggunaan air permukaan yang berasal dari sungai. Pembangunan tampungan air ini perlu disertai dengan pemeliharaan daerah tangkapan air untuk menjaga keberlanjutan sumber air pada tampungan tersebut dengan melakukan pembangunan berbasis DAS dan perlindungan terhadap RTH.

\section{Prinsip 5. Pembangunan terkendali (Anti-sprawl development)}

Wilayah IKN merupakan wilayah yang memiliki ekosistem sensitif sehingga memerlukan pengendalian dalam pembangunannya terutama pembangunan kota. Pembangunan kota ini harus berbasis daya dukung dan daya tampung lingkungan. Dengan menerapkan pembangunan permukiman yang kompak diharapkan dapat mengurangi ketergantungan pada mobil pribadi, perlindungan pada daerah peri-feri, dan daerah hijau, serta menyediakan akses yang lebih baik kepada fasilitas dan layanan kota. Hal ini juga dapat dilakukan dengan pembuatan greenbelt yang mengelilingi kota untuk membatasi pemekaran kota terutama yang berpotensi pada biodiversity hotspot dan mempertahankan daya dukungnya terhadap masyarakat serta meningkatkan kualitas lingkungan.

\section{Prinsip 6. Community Engagement atau Pelibatan Masyarakat}

Hutan dan lingkungan memberikan manfaat yang cukup besar kepada masyarakat. Keberlanjutan hutan dan lingkungan sangat tergantung pada kegiatan yang dilakukan oleh manusia ataupun masyarakat. Oleh karena itu, sangat penting untuk memberikan pendidikan lingkungan yang dapat membangun kesadaran masyarakat akan pentingnya hutan maupun pohon secara khusus bagi kehidupan serta meningkatkan kesadaran dan membantu masyarakat membuat pilihan yang lebih ramah lingkungan. Hal ini juga dapat dilakukan dengan mengadopsi kearifan masyarakat lokal khususnya dalam pemanfaatan sumber daya hutan yang dapat juga menjadi representasi identitas bangsa. Selain itu, bentuk keterlibatan masyarakat untuk mendukung terciptanya Forest City dapat juga dilakukan dengan melibatkan masyarakat sebagai citizen forester, baik dalam penanaman pohon maupun pengelolaan dan monitoring pohon di perkotaan.

Selanjutnya prinsip-prinsip tersebut diterjemahkan ke dalam kriteria dan indikator (Tabel 3) untuk memastikan setiap prinsip dapat terpenuhi di dalam perencanaan pembangunan IKN.

Tabel 3. Prinsip, Kriteria dan Indikator Konsep Forest City

\begin{tabular}{|c|l|l|l|}
\hline No & \multicolumn{1}{|c|}{ Prinsip } & \multicolumn{1}{|c|}{ Kriteria } & \multicolumn{1}{c|}{ Indikator } \\
\hline 1 & $\begin{array}{l}\text { Konservasi sumber } \\
\text { daya alam dan habitat } \\
\text { satwa }\end{array}$ & $\begin{array}{l}\text { Menjaga dan memperbaiki } \\
\text { kualitas tutupan lahan yang } \\
\text { baik }\end{array}$ & Persentase minimal tutupan hutan \\
- Tersedianya RTH berstruktur hutan
\end{tabular}




\begin{tabular}{|c|c|c|c|}
\hline \multirow[t]{3}{*}{ No } & Prinsip & Kriteria & Indikator \\
\hline & & $\begin{array}{lr}\text { Pelestarian } & \text { dan } \\
\text { perlindungan } & \text { kehati } \\
\text { (termasuk habitat satwa) }\end{array}$ & $\begin{array}{l}\text { - Distribusi usia pohon dalam suatu } \\
\text { komunitas } \\
\text { - Tersedianya Informasi kondisi pohon } \\
\text { - Menggunakan vegetasi tanaman } \\
\text { lokal } \\
\text { - Distribusi spesies yang merata } \\
\text { - Tersedianya koridor penghubung } \\
\text { - habitat satwa } \\
\text { - Spesies invasif yang terkendali }\end{array}$ \\
\hline & & $\begin{array}{l}\text { Perlindungan } r \text { terhadap } \\
\text { kawasan bernilai konservasi } \\
\text { tinggi }(\mathrm{NKT})\end{array}$ & $\begin{array}{l}\text { - Penetapan kawasan lindung untuk } \\
\text { kawasan yang memiliki NKT } \\
\text { - Penetapan Buffer zone }\end{array}$ \\
\hline \multirow[t]{2}{*}{2} & \multirow[t]{2}{*}{$\begin{array}{l}\text { Terkoneksi dengan } \\
\text { alam }\end{array}$} & $\begin{array}{lll}\text { Penyediaan } & \text { RTH } & \text { yang } \\
\text { terintegrasi } & & \end{array}$ & 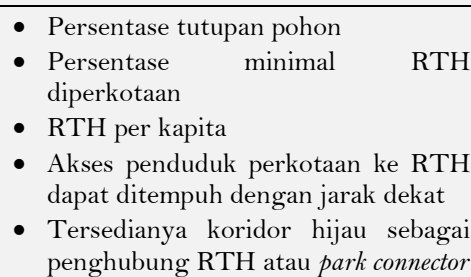 \\
\hline & & Design with nature & $\begin{array}{l}\text { - Perubahan bentang alam yang } \\
\text { minimal dalam pembangunan } \\
\text { - Pembangunan pada lahan yang tidak } \\
\text { bertutupan hutan } \\
\text { - Tesedianya pekarangan di setiap } \\
\text { persil } \\
\text { - Bangunan hijau/ramah lingkungan }\end{array}$ \\
\hline \multirow[t]{4}{*}{3} & \multirow[t]{4}{*}{$\begin{array}{l}\text { Pembangunan } \\
\text { rendah karbon }\end{array}$} & Penyerapan karbon tinggi & $\begin{array}{l}\text { - Persentase minimal tutupan hutan } \\
\text { - Target cadangan karbon }\end{array}$ \\
\hline & & Penurunan emisi & $\begin{array}{l}\text { - Penggunaan emisi GRK per Unit } \\
\left.\left(\mathrm{tCO}_{2} / \mathrm{ha}\right) \text { atau ( } \mathrm{tCO}_{2 \mathrm{eq}} / \mathrm{ha}\right) \\
\text { - } 100 \% \text { clean energy (penggunaan energi } \\
\text { baru dan terbarukan) } \\
\text { - Dominasi penggunaan transportasi } \\
\text { publik di tengah kota } \\
\text { - Transportasi publik zero emission }\end{array}$ \\
\hline & & Kualitas udara yang baik & $\begin{array}{l}\text { - Konsentrasi } \mathrm{PM}_{2.5} \text { rendah } \\
\text { - Bebas asap (haze) } \\
\text { - Bebas timbal }(\mathrm{Pb}) \\
\text { - POPs rendah } \\
\text { - ISPU baik }\end{array}$ \\
\hline & & Suhu udara rata-rata sejuk & Suhu ambien $28^{\circ} / 25^{\circ} \mathrm{C}$ \\
\hline \multirow[t]{2}{*}{4} & \multirow[t]{2}{*}{$\begin{array}{l}\text { Sumber daya air yang } \\
\text { memadai }\end{array}$} & $\begin{array}{l}\text { Kualitas dan kuantitas air } \\
\text { baku yang tergolong baik }\end{array}$ & $\begin{array}{l}\text { - Tutupan lahan hulu DAS yang } \\
\text { terjaga } \\
\text { - Karakteristik kimia, biologi dan fisik } \\
\text { air yang tergolong baik } \\
\text { - Konsumsi air yang efisien }\end{array}$ \\
\hline & & $\begin{array}{lll}\text { Kemudahan } & \text { akses } & \text { publik } \\
\text { terhadap air } & & \\
\end{array}$ & $\begin{array}{ll}\text { - Ketersediaan infrastruktur air yang } \\
\text { memadai } \\
\text { - Infrastrutur tampungan air hujan }\end{array}$ \\
\hline 5 & $\begin{array}{l}\text { Anti-Sprawl } \\
\text { Development }\end{array}$ & Dense and compact settlements & $\begin{array}{l}\text { - Pemanfaatan sekitar 50\% wilayah } \\
\text { kota untuk dikembangkan sebagai } \\
\text { lahan terbangun } \\
\text { - Konsentrasi pembangunan pada } \\
\text { pusat kota }\end{array}$ \\
\hline
\end{tabular}




\begin{tabular}{|c|c|c|c|}
\hline No & Prinsip & Kriteria & Indikator \\
\hline \multirow[t]{2}{*}{6} & \multirow[t]{2}{*}{$\begin{array}{l}\text { Melibatkan } \\
\text { masyarakat }\end{array}$} & Peran aktif masyarakat & $\begin{array}{l}\text { - Masyarakat sadar lingkungan } \\
\text { - Citizen Forester } \\
\text { - Komunitas lingkungan }\end{array}$ \\
\hline & & $\begin{array}{l}\text { Mengadopsi kearifan lokal } \\
\text { dalam pengelolaan hutan }\end{array}$ & $\begin{array}{l}\text { - Teridentifikasinya kelola masyarakat } \\
\text { pada area berhutan di IKN } \\
\text { - Masyarakat lokal terlibat dalam } \\
\text { perencanaan dan pengelolaan hutan } \\
\text { - Reboisasi/rehabilitasi mengadobsi } \\
\text { praktek pengelolaan hutan oleh } \\
\text { masyarakat lokal }\end{array}$ \\
\hline
\end{tabular}

\section{Kesimpulan dan Tindak Lanjut}

Beberapa hal yang harus diperhatikan untuk menerapkan Konsep Forest City dalam pembangunan IKN adalah sebagai berikut:

- Pemantapan kawasan hutan dan penyelesaian berbagai konflik lahan di dalam kawasan hutan yang perlu dilakukan sebelum membangun IKN.

- Mengintegrasikan Konsep Forest City ke dalam Masterplan IKN dan berbagai produk perencanaan kota dan wilayah lainnya termasuk tata ruang.

- Melaksanakan pembangunan IKN dengan memperhatikan daerah-daerah yang memiliki fungsi hutan maupun fungsi penting dalam keberlanjutan lingkungan. Hal ini dapat dilakukan dengan memperhatikan go area dan no go area seperti yang telah ditentukan pada KLHS Masterplan IKN.

- Menyediakan RTH kota berdasarkan kebutuhan perlindungan habitat yang sensitif secara ekologi (satwa dan tumbuhan lokal); kemampuan menghasilkan oksigen dan menyerap karbon dioksida; kemampuan untuk menyerap berbagai jenis polutan; serta kemampuan penyerapan air hujan.

- Menyusun tahapan pemulihan dan rehabilitasi SDALH di kawasan IKN sebagai upaya pemulihan kawasan hutan dengan rehabilitasi kawasan yang terdegradasi serta pembangunan koridor satwa dan koridor hijau.

- Membuat kelembagaan pengelolaan hutan dan kehati seperti independent advisory board atau independent agency yang didukung oleh pemerintah.

Penerapan Konsep Forest City ini tidak hanya terbatas pada konteks kota saja tetapi diharapkan juga terintegrasi dengan wilayah sekitarnya, terutama untuk mendukung keberlanjutan hutan dan lingkungan secara umum. Pada hakikatnya wilayah dan kota yang berdampingan merupakan satu ekosistem yang saling berpengaruh. Oleh karena itu, dalam perencanaan dan pembangunan kota akan sangat bergantung terhadap perencanaan dan kebijakan masing-masing wilayah.

\section{Daftar Pustaka} Architetti,
https://www.stefanoboeriarchitetti.net/en/project/smart-forest-city-cancun/ 
Atlanta Magazine. (2015). It takes a forest: How intown development puts Atlanta's tree canopy at risk. https://www.atlantamagazine.com/news-culture-articles/it-takes-a-foresthow-intown-development-puts-atlantas-tree-canopy-at-risk/

B.A. Blackwell and Associates Ltd. (2014). City of London Urban Forest Strategy. Technical Report.

Bentsen, P., Lindholst, A. C., \& Konijnendijk, C. C. (2020). Reviewing Eight Years of Urban Forestry \& Urban Greening: Taking Stock, Looking Ahead. Urban Forestry \& Urban Greening.

CDIC. (2018). China to have 300 forest cities by 2025. http://www.chinadaily.com.cn/a/201807/09/WS5b429dcba3103349141e169e.htm 1

Guan, X., Jones, D., \& Roos, P. (2018). Biophilic city, vertical city, Forest City? Towards an Architectee, 814-826.

IEA. (2008). World Energy Outlook 2008. Retrieved from International Energy Agency: http://www.iea.org/textbase/nppdf/free/2009/transport2009.pd

Kementerian Lingkungan Hidup dan Kehutanan (KLHK). (2020). Kajian Lingkungan Hidup Strategis Masterplan IKN. KLHK.

PBB. (2012). Agenda Baru Perkotaan. Sekretariat Habitat III.Quito, Equador.

Roy, S., Byrne, J., \& Pickering, C. (2012). Systematic Quantitative Review of Urban Tree Benefits, Costs, and Assessment Methods Across Cities in Different Climatic Zones. Urban Forestry \& Urban Greening, $11(4), 351363$.

Seymour, F. (2018). Reasons City Dwellers Should Care About Forests. Retrieved from WRI. https://wri-indonesia.org/en/blog/3-reasons-city-dwellers-should-care-abo Forest City pada kota-kota di dunia ut-forests

Shao, F., \& Xie, X. D. (2019). The Master Planning and Construction Plan of Forest Cities Based on Low Carbon Effect. Applied Ecology and Environmental Research, 17(4), $9401-$ 9410. https://doi.org/: http://dx.doi.org/10.15666/aeer/1704_94019410

Sulistioadi, Y. B., Hussin, Y. A., \& Sharifi, M. A. (2004). Identification of high conservation value forest (HCVF) in natural production forest to support implementation of SFM certification in indonesia using remote sensing and GIS. International Journal of Applied Earth Observation and Geoinformation, 35(7), 164-169.

UPTD Tahura Bukit Soeharto. (2019). Blok Pengelolaan Taman Hutan Raya Bukit Soeharto di Kabupaten Kutai Kartanegara dan Kabupaten Penajam Paser Utara Provinsi Kalimantan Timur. Samarinda: Dinas Kehutanan Pemerintah Provinsi Kalimantan Timur.

Xu, C., Dong, L., Yu, C., \& Zhang, Y. (2020). Can Forest City Construction Affect Urban Air Quality? The Evidence from The Beijing-Tianjin-Hebei Urban Agglomeration of $\begin{array}{llll}\text { China. Journal of Cleaner } & \end{array}$ https://doi.org/10.1016/j.jclepro.2020.121607

Biehn N. (2013). “The Missing V's in Big Data: Viability and Value. Wired. Available from: http://www.wired.com/insights/2013/05/the-missing-vsin-big-data-viability-andvalue/.

Boyd, D. and Crawford, K. (2012). "Critical Questions for Big Data. Information, Communication, \& Society. 15(5). pp. 662-679.

EDUCBA. (2019). "Data Analytics vs Data Analysis". In www.educba.com.

Gartner. (2014). "IT Glossary Big Data". Available in http://www.gartner.com/itglossary/big-data/.

Grimes, S. (2013) “Big Data: Avoid 'Wanna V' Confusion. Information Week. Available from: http://www.informationweek.com/big-data/big-data-analytics/big-dataavoidwannaconfusion/d/d.

Jacobs, A. (2009). "The pathologies of Big Data”. Communications of the ACM. 52(8). pp. 36-44. 
Kraska, T. (2013). "Finding the Needle in the Big Data Systems Haystack". IEEE Internet Computing. 17(1). pp. 84-86.

Loshin, D. (2009). "Big Data Analytics". Waltham. Morgan Kaufmann.

Marr, B. (2015) "Why Only One of the 5 Vs of Big Data Really Matters". IBM Big Data \& Analytics Hub. Available from: http://www.ibmbigdatahub.com/ blog/why-onlyone-5-vs-big-data-really-matters.

Mazzei, Mattew J. and Noble, David. (2019). "Big Data and Strategy: Theoretical Foundations and New Opportunities. http://dx.doi.org/10.5772/intechopen.84819.

Megahed, F.M. and Jones-Farmer, L.A. (2013). "A Statistical Process Monitoring Perspective on Big Data”. In Frontiers in Statistical Quality Control. 11th ed. New York. Springer.

McAfee, A. and Brynjolfsson, E. (2012). “Big Data: The Management Revolution”. Harvard Business Review. 90(10). pp.60-68.

Morabito, V. (2015). "Big Data and Analytics: Strategic and Organizational Impacts". Switzerland. Springer.

Porter, M.E. and Heppelmann, J.E. (2014). "How Smart, Connected Products are Transforming Competition”. Harvard Business Review. 92(11). pp. 64-88.

Republik Indonesia. (2019). "Peraturan Presiden Republik Indonesia Nomor 39 Tahun 2019 Tentang Satu Data Indonesia”.

Riahi, Youssra and Riahi, Sara. (2016). "Big Data Analytics: Challenges and Applications for Text, Audio, Video, and Social Media Data". International Journal on Soft Computing, Artificial Intelligence and Applications (IJSCAI). Vol. 5. No. 1. February.

Riahi, Youssra and Riahi, Sara. (2018). "Big Data and Big Data Analytics: Concepts, Types and Technologies”. International Journal of Research and Engineering. Vol. 5. No. 9. September-October. pp. 524-528.

UN Global Pulse. (2012). "Big Data for Development: Challenges and Opportunities".

van Rijmenam, M. (2014). "Think Bigger: Developing a Successful Big Data Strategy for Your Business". New York. Amacom.

Wu, X. Zhu, X. and Wu, G. (2014). "Data Mining with Big Data”. IEEE TKDE. 26. pp. 97107.

Zikopoulos, P. Eaton, C. de Roos, D. Deutsch, T. Lapis, G. (2012). "Understanding Big Data: Analytics for Enterprise Class Hadoop and Streaming Data”. New York. McGrawHill. 